\title{
Socioeconomic impacts of resource diversification from small-scale fishery development
}

\author{
$\underline{\text { Steven W. Purcell }}^{1}$, Alejandro Tagliafico ${ }^{1}$, Brian R. Cullis $^{2,3}$ and Beverley J. Gogel $^{2,3}$
}

\begin{abstract}
The predicted future shortfall in seafood production from tropical small-scale fisheries demands support to help diversify income streams and food production for coastal communities. Livelihood diversification can comprise the enhancement or addition of components to existing fisheries, yet the likely socioeconomic impacts are unclear. With a long history of nondeleterious introductions, the marine snail "trochus" (Rochia nilotica) was introduced to Samoa from 2003 to 2006 to offer a new artisanal fishery resource. Some 15 years later, we surveyed 303 fishers using structured questionnaires and mixed effects models to evaluate how the fishery has contributed to fisher well-being and what factors have influenced the socioeconomic impacts. Most fishers consumed part of their catch and both fisherwomen and fishermen shared harvests informally within communities, thereby bolstering resilience of the socialecological systems at the community level. More than one-quarter of fishers sold part of their catch and the new earnings represented $17 \%$ of their gross income from all sources. Fishing incomes were gender equitable and influenced by fishing frequency and capital assets (boats). Most fishers were satisfied with income from the relatively new fishery and improved income was reported by a majority of fishers, especially those younger and less experienced. Additional money from the fishery was most often spent on food, church tithing, and school fees. This relatively new fishery fostered positive well-being outcomes that were gender inclusive. Extrapolations of annual incomes across the fishery reveal a rapid return on investment from foreign-aid funded development. The study reveals that certain coastal artisanal fisheries can be gender equitable and that benefits are likely underestimated because of subsistence consumption and informal distribution networks. Diversifying the marine resources accessible to small-scale fishers offers a promising strategy to support coastal livelihoods and strengthen resilience of social-ecological systems.
\end{abstract}

Key Words: artisanal fisheries; coastal livelihoods; economics; gender; invertebrate fisheries; small-scale fishing; social-ecological systems

\section{INTRODUCTION}

\section{Diversifying small-scale fisheries}

Small-scale fisheries (SSFs) provide livelihood and nutrition to millions of coastal people worldwide (Chuenpagdee et al. 2006, Mills et al. 2011) yet are threatened by increasing fishing pressure and external stressors (Kolding et al. 2014). Diminished fishery productivity can erode resilience of social-ecological systems, especially where resource diversity is low (Nayak et al. 2014). In small-island developing states, seafood consumption can be remarkably high and represent the main source of protein (Bell et al. 2009, Charlton et al. 2016). With increasing populations, and continued reliance on local seafood, Bell et al. (2009) predict that coastal fisheries will struggle to meet the consumptive demands of coastal communities in the Pacific Islands. Sustaining a "safe and just space" for small-scale fishers in the Blue Economy into the future compels initiatives that maintain human well-being of coastal and marine-resource dependent people (Cohen et al. 2019).

Programs to diversify fisher livelihoods through nonfishery income streams, i.e., "pluriactivity" or "occupational diversification," could take pressure off fish stocks in SSFs (Allison and Ellis 2001, Salmi 2005). However, alternative economic opportunities are an ongoing challenge for island countries, such as those in the Pacific (Pollard and Abbott 2004, SPC 2015). Further, fishers might not want to take up other occupations because they enjoy fishing (Pollnac et al. 2001, Cinner
2014) and because it sustains tradition and diets in coastal households (Kawarazuka and Béné 2010, Loring et al. 2019).

Diversifying the marine resources accessible to fishers is an alternative approach to sustaining SSFs (Cinner 2014, Finkbeiner 2015, Stacey et al. 2019). This could arise from programs to train fishers in new gear and techniques, or establish markets for previously unexploited species (Bell et al. 2018), or the introduction of new commercial species (Andréfouët et al. 2014, Tioti and Bermudes 2016). Such initiatives can build adaptive capacity, through the substitution of food resources for coastal fishers, thereby reducing food security vulnerability (see Hughes et al. 2012). When fishers share their catch with others, diversified harvests can enhance resilience of social-ecological systems at the community level (Vaughan and Vitousek 2013). Fishery development should aim to be gender inclusive (Bell et al. 2009, Koralagama et al. 2017), especially because poverty and hardship are often strongly influenced by an inadequate access to income opportunities (Allison and Ellis 2001, Pollard and Abbott 2004). The planning of such programs would thus greatly benefit from research into how small-scale fishers respond to, and benefit from, resource diversification. How are newly accessed resources shared or traded within communities; are the impacts of resource diversification gender equitable; what are the potential factors that influence income to fishers and how is the fishery income used; and do newly accessed resources contribute to other dimensions of well-being?

\footnotetext{
${ }^{1}$ National Marine Science Centre, Southern Cross University, Coffs Harbour, New South Wales, Australia, ${ }^{2}$ School of Mathematics and Applied Statistics, National Institute for Applied Statistics Research Australia, ${ }^{3}$ Faculty of Engineering and Information Sciences, University of Wollongong, Wollongong, Australia
} 
In Samoa, an autonomous central-western Pacific Island country, shellfish resources are sparse and the native species are small, offering limited seafood to coastal villages (Tiitii and Aiafi 2016). A recent introduction (2003-2006) to Samoa of a larger and more productive marine snail, called "trochus" (Rochia nilotica), aligns with Blue Economy aspirations of "increasing food production from the sea" (Cohen et al. 2019). The nascent fishery offered an opportunity to examine the above questions about socioeconomic impacts of livelihood diversification through a relatively new component to existing fishing livelihoods (sensu Stacey et al. 2019).

\section{Small-scale fisheries income and well-being}

Many SSFs in the tropics focus on tropical invertebrates that are eaten, traded, or sold locally. Harvesting of coastal shellfish is widespread because they can be collected by hand and with little fishing gear or experience (Gillett and Tauati 2018). Consequently, shellfish fisheries often involve both men and women, youth and elderly, in fishing and postharvest processing (Chuenpagdee et al. 2006, Fröcklin et al. 2014, Santos 2015). Generally, low-value invertebrates are eaten by fishers and their families while high-value species and shells are sold, contributing to the general household income (Fröcklin et al. 2014).

Income generation from invertebrate fisheries can differ enormously among countries, depending on target species and markets (Gillett and Tauati 2018). For instance, fishers in Pacific Islands targeting sea cucumbers might have relatively high annual incomes (Purcell et al. 2018, Hair et al. 2019) compared with fisher incomes in artisanal fisheries in Africa (Fröcklin et al. 2014, Belhabib et al. 2015). Nonetheless, domestic seafood sales are still vital for local economies and household incomes in numerous countries (Gillett 2009, Mills et al. 2011). Such artisanal fisheries for shellfish and other invertebrates are often undervalued and underreported in fisheries databases (Zeller et al. 2006, Béné et al. 2015).

The importance of small-scale fisheries to income generation has been widely touted (Mills et al. 2011, Belhabib et al. 2015), yet few studies have compared fishing incomes with other income of fishers (Allison and Ellis 2001, Purcell et al. 2018). Income varies greatly among different types of fishers and fishing métiers (Fröcklin et al. 2014, Purcell et al. 2018). Such disparities can arise from individual behaviors, fishing efficiency, and socioeconomic circumstances (Faraco et al. 2016), and the ecosystem and fishing gear used by fishers (de la Torre-Castro et al. 2017). Boat and fishing gear can allow access to more profitable fishing grounds and/or increase catch rates, thereby improving incomes (Kuster et al. 2005).

Gendered division of labor can exist in fisheries, but Weeratunge et al. (2010) argue that research should move beyond this limited perspective. Gender inequality in fisheries income is widely known (Zhao et al. 2013, Teh et al. 2020), yet the underlying causes are diverse. Compared to male fishers, women could be disadvantaged by being restricted to just gleaning, processing, and selling activities (Santos 2015, Furkon et al. 2019), being restricted to intertidal areas (Siar 2003, de la Torre-Castro et al. 2017), having poorer access to boats (Gerrard and Kleiber 2019), being given lower prices by traders (Purcell et al. 2016), and even being excluded in some fisheries, thus obtaining less catch (Chapman 1987, Hauzer et al. 2013). Women might invest less time in fishing because of their involvement in child raising, farming, caring for elders, and housekeeping (Harper et al. 2013, de la Torre-Castro et al. 2017, Biswas 2018).

Gendered disparities in fishery income might also be attributable to the proclivity of women to retain part of their catch for subsistence consumption (Harper et al. 2013, Gillett and Tauati 2018). In certain cultures, men are held as income earners and so might sell a comparably larger part of their catch (Kronen et al. 2007, Fröcklin et al. 2014). Consequently, while prices and landings for harvested seafood might be gender equitable, women fishers might gain lower weekly income (de la Torre-Castro et al. 2017, de la Torre-Castro 2019). Thus, framing poverty in Pacific Island fisheries on income alone might be inadequate because fisheries contribute substantially to local diets (Pollard and Abbott 2004, Charlton et al. 2016).

Fishery catches and incomes strongly influence fisher well-being. The concept of well-being includes their economic yield, food supplies, employment, and psychological and physical health (Coulthard et al. 2011, Weeratunge et al. 2014). Satisfaction with one's livelihood source is one, of many, useful measures of wellbeing, derived directly from socioeconomic surveys (Coulthard et al. 2015, Purcell et al. 2016). Fishery dissatisfaction can impact on fishers' mental and physical health (Coulthard et al. 2015, Pollnac and Poggie 2006), and undermine the relationships between fishers and management institutions (Trimble and Johnson 2013). An integration of objective (e.g., food or income) and subjective well-being measures (e.g., satisfaction) thus offers a more holistic perspective on impacts within social-ecological systems (Weeratunge et al. 2014).

\section{Trochus: a nascent fishery in Samoa}

Pacific Island states rely on foreign aid for fishery-related development assistance (Hanich and Tsamenyi 2009). Billions of dollars in official development assistance have been destined to support nutrition and livelihood of fishers worldwide (Blasiak and Wabnitz 2018). Several case examples have illustrated positive socioeconomic impacts from foreign-aid diversification of fisheries in Pacific Island countries. For instance: seaweed farming in Fiji (Lal and Vuki 2010), pearl oyster farming in the central Pacific (Fong et al. 2005), and green snail introduction in French Polynesia (Andréfouët et al. 2014). These projects directly or indirectly benefited coastal communities improving their adaptive capacity, income, and well-being.

Trochus is a commercially important herbivorous marine snail of the western Pacific (Nash 1993, Gillett and Tauati 2018). It has long been harvested for export of its shell (Gillett and Tauati 2018), and is avidly consumed locally (Foale and Day 1997, Nash 1993). In Samoa, native reef shellfish (e.g., Tectus pyramis and Turbo chrysostomus) were relatively small and naturally sparse (Purcell and Ceccarelli 2021), offering limited yields for artisanal fishers. Being a larger and often more abundant animal, trochus by contrast has been a substantial fishery resource in other Pacific Islands but was not endemic to Samoa until recently (Tiitii and Aiafi 2016, Purcell and Ceccarelli 2021). Trochus has been translocated to new localities beyond its distribution, including Cook Islands, French Polynesia, Tonga, and Hawaii with little evidence of any negative ecological impacts of the introductions spanning 90 years (Bell et al. 2005, Gillett and Tauati 2018). Owing to its fishery potential and low risk of ecological impact, the 
Samoan Ministry of Fisheries introduced trochus to its reefs in 2003-2006 with support from Australia's foreign aid program (ACIAR Project FIS/2001/085). This was done primarily through translocations of broodstock animals from Fiji and Vanuatu. The intention was to diversify seafood and potential revenue for local communities, weighed against potential biodiversity risks (Tiitii and Aiafi 2016). Abundant colonization of trochus occurred within 15 years, and they are now many times denser at some reef sites than the native herbivorous gastropods (Seinor et al. 2020, Purcell and Ceccarelli 2021). Trochus has become an additional seafood resource for more than 1000 small-scale fishers in Samoa, second-most harvested (after fish) by many fishers (Purcell et al. 2020).

\section{Aims and objectives of this study}

We assessed the socioeconomic impacts of the nascent trochus fishery in Samoa using gender-disaggregated data from questionnaire-based surveys of fishers across multiple coastal villages. Specifically, we sought to determine the key factors that influence income, fishing costs, subsistence consumption, trade, and indices of well-being in this social-ecological system. We apply a robust examination of gender equity in fishery outcomes by using quantitative mixed-model analyses to account for correlated factors that vary alongside gender groupings (Purcell et al. 2020). Estimates of the number of fishers in the fishery and our data on average annual income of fishers allow an appraisal of the annual economic potential of shell exports. The research approach allows us to examine how island communities can benefit from fishery development, and offers new insights into evaluating gender equity and potential drivers of livelihood outcomes in social-ecological systems.

\section{MATERIALS AND METHODS}

\section{Study sites}

Data were collected from November to December 2018 in villages around both of Samoa's main islands: Upolu (19 villages) and Savai'i (15 villages; Fig. 1). Villages were chosen in consultation with the Fisheries Division of the Ministry of Agriculture and Fisheries (MAF), Samoa. The villages were those in which trochus was known to be collected, but we did not base the selection on other variables.

\section{Data collection}

On average, 9 fishers (range $=6-10$, median $=9$ ) were interviewed in each village, subject to their availability. In total, 303 fishers were interviewed. Some villages had fewer than 10 fishers. Apart from consulting with the village mayor, we used snowball sampling to locate active fishers. Fishers could be exclusively fishing (for consumption and sharing), or fishing and selling. The few encountered sellers who did not also fish for trochus were not interviewed. We also employed a gender-inclusive approach (Kleiber et al. 2015), whereby women fishers were interviewed where possible in order to ensure their representation. Sampling allowed for any person who collected trochus within the past year, regardless of their age, gender, or the frequency or purpose of fishing. Respondents ranged from 16 to 68 yr old (average $=38$ ).

The surveys were approved (SCU: ECN-18-204) for ethical human research and overseas research and followed guidelines of the Australian National Statement on Ethical Conduct in Human
Research 2007. The Ministry of Women's Affairs in Samoa granted additional approval. We sought and obtained authorization to conduct the interviews from the chiefs or mayors of each village. Information sheets about the research were given to each interviewed fisher, and all interviewees gave written consent to be interviewed and for the data to be used in the research.

Fig. 1. Map of Samoa showing locations of the 34 study villages in which fishers were interviewed (red dots).

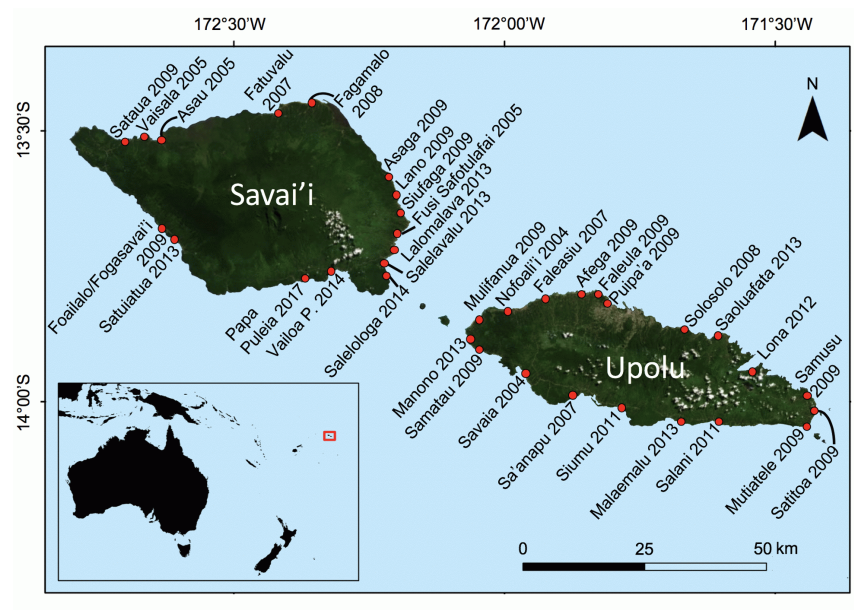

Interviews using a structured questionnaire (Appendix 1) were conducted at either the fishers' homes or in an open place within villages (Fig. 2). Interviews took 25-40 min to complete and were facilitated by an interpreter when conducted by a foreign researcher (SWP). To derive response variables, we asked each fisher questions including (but not restricted to) the following: their perceived weekly income from fishing trochus based on an average-day catch over the past year; perceived weekly income from all livelihood sources; amount and cost of fuel used on their last fishing trip and how many fishers shared the fuel costs; average number of fishing trips per week; number of months per year not fishing; costs of various fishing gear and frequency of purchase; income earned from the last recalled sale of trochus and days taken to harvest those animals sold; and what portions of the trochus were eaten themselves, given away, i.e., shared, and sold. To obtain potential explanatory covariates from fishers, we recorded their gender, age, years of fishing experience, fishing methods, boat use, weekly fishing frequency, place of sale if they sold part of the trochus they caught, and if they sold the empty shells. A conversion rate of US\$0.385 per WS\$ at the time of the surveys was applied.

Fishery officers of MAF collectively provided conservative estimates of the number of trochus fishers in nonsurveyed coastal villages around Upolu and Savai'i. The sum of those village estimates was added to the sum of data on the median numbers of fishers reported in our study villages (based on median responses of fishers), yielding a total estimate of fishers for both Upolu and Savai'i. Annual total gross income to fishers for the entire fishery was derived by multiplying the questionnairederived data on average gross annual income per fisher in Upolu and Savai'i, separately, by the estimated number of trochus fishers on each island. 


\section{Statistical analysis}

Linear mixed models (LMM) or generalized linear mixed models (GLMM) were used to analyze each response variable. The analyses were performed using ASReml-R, a powerful linear mixed modeling software that can fit a wide range of potentially complex treatment and covariance structures (Butler et al. 2018). Explanatory variables were classed as anatomical (factors and covariates of prime interest) or secondary (factors or covariates that could reduce error or explain variation) and were fitted as either fixed or random model terms in the model (Table A2.1). The secondary variables were retained in each final model with no variable selection. The significance of the fixed terms was assessed using a Wald test (Butler et al. 2018) and the percentage of total variation explained by each of the random terms was calculated for each response variable.

Fig. 2. (a, b) Conducting interviews with trochus fishers; (c) a young fisher selling trochus (Rochia nilotica) flesh in bottles; (d) a pile of trochus shells on sale by the roadside in Savai'i; (e) trochus flesh in bottles for sale in a town market in Savai'i; (f) two Samoan fishers in a typical traditional paddle canoe during a trip to collect trochus and other seafood; (g) a pile of trochus shells broken by fishers in order to extract the uncooked flesh. All persons depicted gave verbal consent to being photographed.
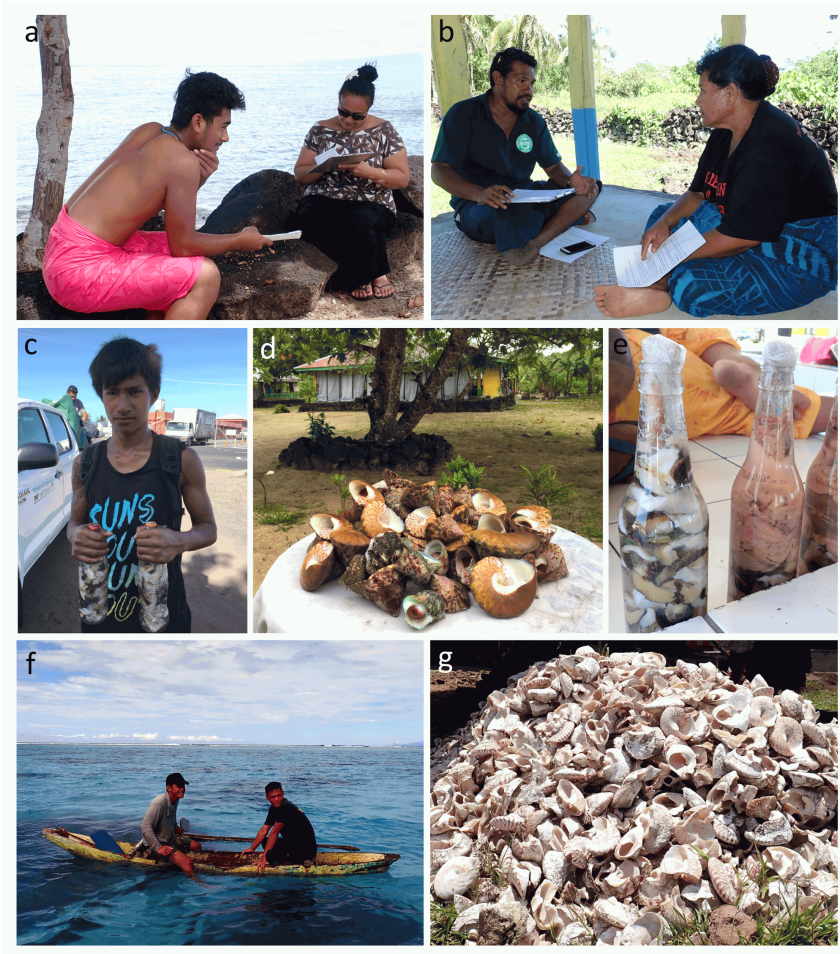

Potential nonlinearity between each response variable and fisher age was examined by fitting a cubic smoothing spline (Verbyla et al. 1999), and with the assistance of added variable plots (Atkinson 1985). Terms that were marginal to higher order terms were not removed from the model. The gender-by-age interaction was removed when nonsignificant $(P>0.05)$. However, given the aim of investigating gendered and geographic variation, random terms involving gender and age were retained for all response variables. Residual plots were inspected for potential outliers and to check model assumptions.

Net annual income from sales of trochus flesh and average gross income per day from fishers' last sale of trochus were calculated for the 88 (out of 303) interviewed fishers who sold trochus. Data for both variables were log-transformed for analysis to meet normality and homogeneity assumptions. A datum for one fisher earning US\$385 per day (WS\$1000) was validated and retained for analysis. Fisher satisfaction with earnings from trochus and the perception of fishers about change to their overall income from selling trochus were also measured for the 88 fishers selling trochus. Fisher satisfaction was an ordinal response on a Likert scale: very dissatisfied, partly dissatisfied, indifferent, mostly satisfied, and very satisfied. These data were analyzed using a 3threshold multinomial ordinal GLMM to accommodate the set of random effects (McCullagh and Nelder 1989). Fisher perception about changes to their overall income from trochus was measured as an ordinal response: income has decreased, income has stayed the same, or income has increased. The data were analyzed using a 2-threshold multinomial ordinal GLMM following the same approach as for fisher satisfaction.

Data on the proportion of trochus given away, i.e., shared with others in their village, was measured as an ordinal response: none given away, small part given away, half given away, most given away, and all given away. The data were analyzed using a 3threshold multinomial ordinal GLMM, as described. Data on the proportion of trochus eaten by fishers themselves was analyzed as an ordinal response variable: none eaten themselves, small part eaten themselves, half of catch eaten themselves, most eaten themselves, or all of the catch eaten themselves. Likewise, data on the proportion of trochus sold by fishers were analyzed as an ordinal response: none sold, small part sold, half sold, most sold, or all sold. These final two response variables were analyzed using a 4-threshold multinomial ordinal GLMM.

\section{RESULTS}

\section{Subsistence consumption}

For 2018, we estimated that 7.0 million ( \pm 2.7 mil, s.e.) trochus were captured across all fishers in Samoa. This corresponds to an average of 42 trochus day ${ }^{-1}$ fisher $^{-1}$ reported across respondents. Most of the catch was retained for subsistence consumption because $71 \%$ of fishers did not sell any of their catch.

A majority of fishers retained at least half of the trochus for their household consumption (Fig. 3a). Personal consumption of trochus varied somewhat among villages (34\% of variation) and was comparable among the factors tested (gender, age, fishing method, and fishing experience; $P>0.05$ ). Half of the fishers $(51 \%)$ gave away a small part of their catch, and almost one-third $(29 \%)$ of fishers gave away half of their catch (Fig. 3b). The proportion of trochus given away did not depend significantly on any of the explanatory variables $(P>0.05)$.

One-third (34\%) of the fishers removed the trochus flesh from the shells themselves, while $30 \%$ of fishers did this task with their spouse, $15 \%$ of fishers did the processing with family members, and the rest did the processing with other people and their children. On average, fishers spent $36 \mathrm{~min}$ in postharvest 
processing for one day's catch. Most fishers (61\%) broke the shell to get the flesh out, while $33 \%$ took the flesh out leaving the shell intact, and $6 \%$ of fishers alternated between the two methods. Fishers who broke the shells (Fig. $2 \mathrm{~g}$ ) spent slightly more time to get the flesh out $\left(1.9 \mathrm{~min} \mathrm{shell}^{-1}\right)$ than fishers who left the shells intact $\left(1.6 \mathrm{~min} \mathrm{shell}^{-1}\right)$.

Fig. 3. Percentage of men and women on Savai'i and Upolu responding to the use of their collected trochus (Rochia nilotica).

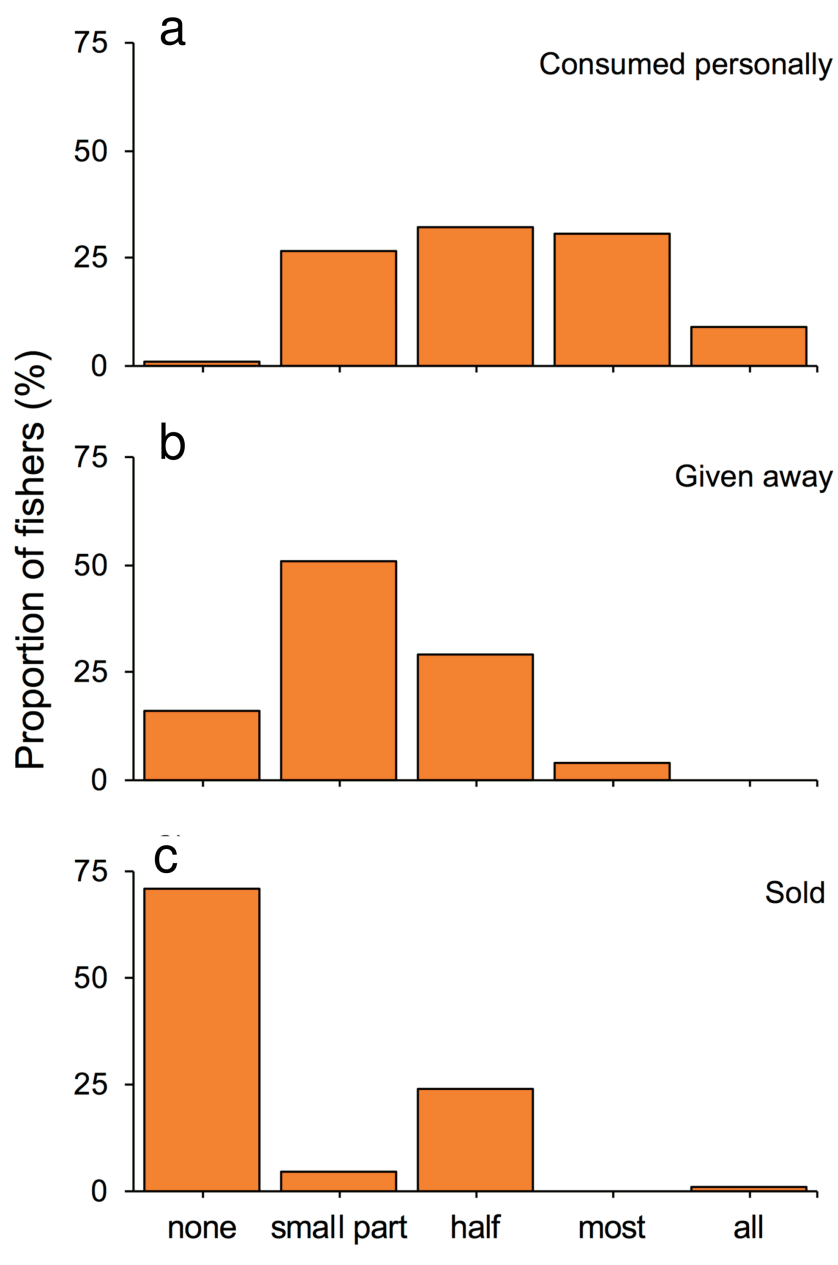

\section{Fishing income and costs}

Net annual income and sales

Fishers who sold trochus earned an average net annual income of US\$1805 \pm 1876 s.d. (WS\$4689 \pm 4873 ) from selling trochus (flesh alone or with shells). This annual income depended significantly on fishing frequency per week $(P=0.002)$, and varied slightly between men and women, according to their village of residence ( $11 \%$ of variation among random model terms), but there was no main effect of gender on annual income. Only one interviewed fisher sold the (empty) shells of trochus.

Fishers who sold trochus invested, on average, US\$106 $\pm 193 \mathrm{~s}$. d. annually in fishing gear and materials, representing $6 \%$ of their gross annual income from trochus (Fig. 4). Fishing costs principally comprised a mask, snorkel, fins, gloves, wetsuit, torch, and batteries. Only $35 \%$ of divers used fins, only $4 \%$ used a wetsuit, and half of the divers (47\%) used cheap swimming goggles without snorkel (cost US\$8-19). A torch was reportedly used by $29 \%$ of fishers, revealing substantial nighttime fishing.

Fig. 4. Average value (US\$ \pm s.e.) of fishing cost per year, trochus (Rochia nilotica) net income per year, and income from all sources per year for men and women that sell trochus on Savai'i and Upolu islands.

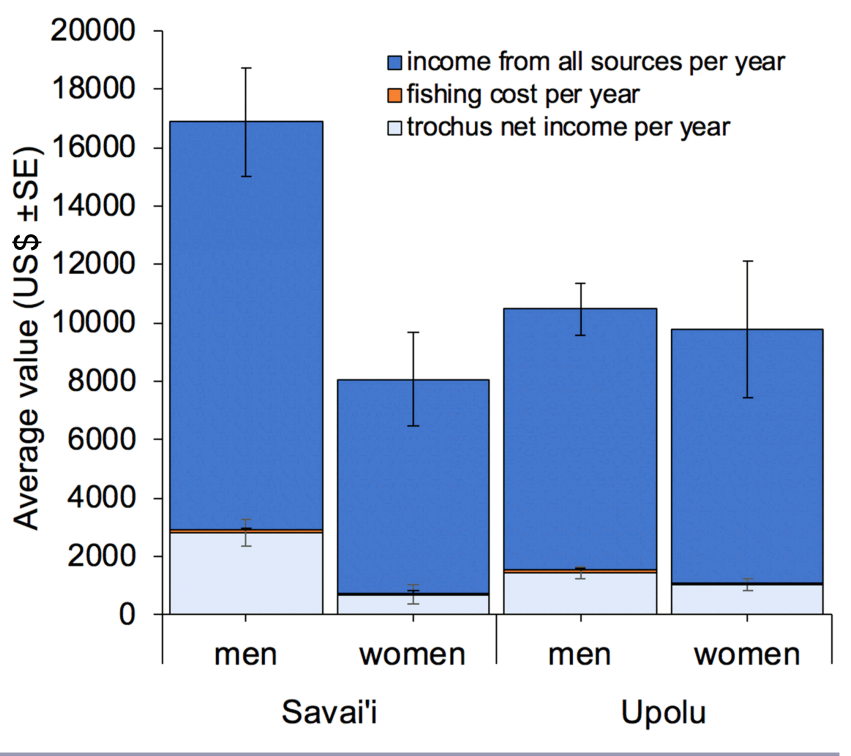

Twenty-nine percent of fishers sold some or all of their trochus catch (Fig. 3c). None of the factors tested (gender, age, fishing method, or fishing experience) significantly affected $(P>0.05)$ the proportion of trochus sold by fishers. The proportion of the trochus catch sold by fishers did not vary between women and men overall, but differed somewhat at the level of specific villages (14\% of variation among random model terms). Around half $(55 \%)$ of the fishers sold their catches from roadside stalls (Fig. 2d), 11\% sold in markets (Fig. 2e), $6 \%$ to households within the village, $5 \%$ using other nonspecified methods (Fig. 2c), 4\% from a village stall, and the rest in combinations of these modes.

Gross income per day

Based on last-sale recall, fishers who sold trochus grossed, on average, US\$37 \pm 44 s.d. per day from fishing and selling trochus. Use of a boat for fishing (Fig. 2f) significantly affected daily gross incomes $(P=0.03)$. Predicted daily incomes (back-transformed) for boat users were more than $50 \%$ greater (US\$30) than nonboat users (US\$19). Fishers with greater fishing frequency (per week) tended to earn more daily income $(P=0.04)$.

\section{Measures of well-being}

Satisfaction

Most fishers were satisfied with income from the fishery (Fig. 5). Specifically, $46 \%$ responded to be very satisfied, $37 \%$ mostly satisfied, $15 \%$ indifferent, and $2 \%$ not very satisfied. The rank of satisfaction in income from trochus was comparable between men and women, and also among the other explanatory variables $(P$ $>0.05$ ). 
Fig. 5. Percentages of fishers per village responding to their satisfaction of income from trochus (Rochia nilotica; only villages with trochus sales reported by some respondents).

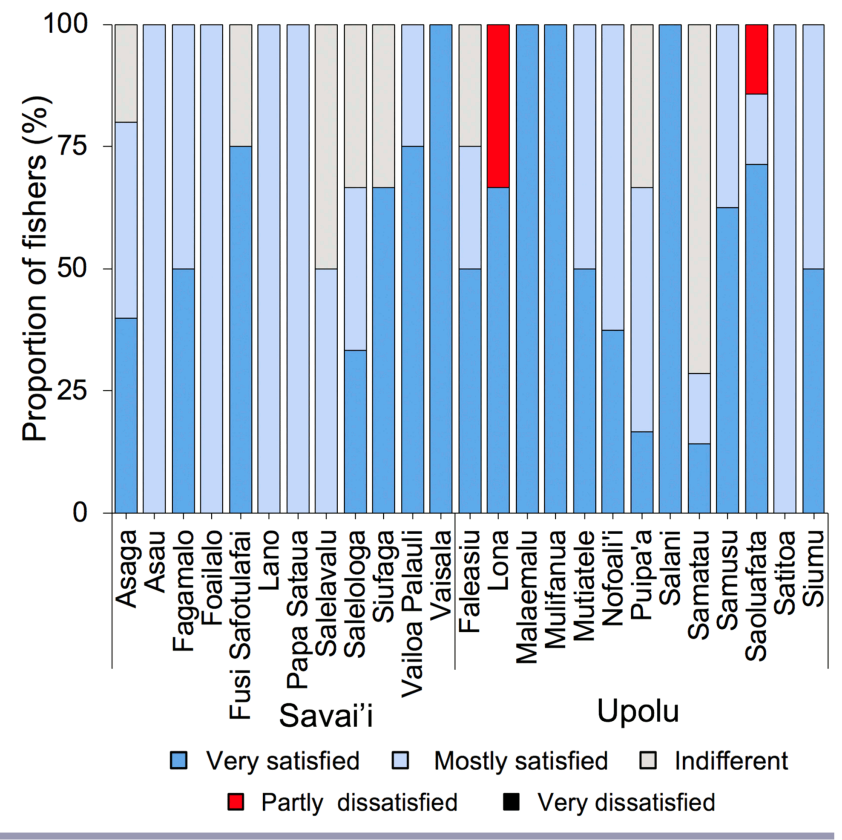

Perception about trochus improving the fisher's income

A slight majority $(59 \%)$ of fishers who sold trochus said that the new fishery resource had improved their income. More than onethird of fishers (39\%) believed that their income was unchanged, while just $2 \%$ said their income had decreased since they started harvesting trochus. There was weak evidence that the perception on changes in income were significantly affected by age $(P=0.041)$ and fishing experience $(P=0.049)$; older fishers and fishers with more years fishing for trochus were less optimistic about their income being improved by the new fishery.

Fishers said that they spent the money earned from trochus sales mainly on food, church, school fees, household expenses, fishing gear, and medical costs (Fig. 6). Fewer fishers spent the additional money on alcohol, home improvements, and other minor expenses.

\section{Valuation of the fishery}

Summed across all revenue sources, the average annual gross income of fishers was US\$10,472. The average gross annual income to fishers from selling trochus was US\$1912 \pm 1901 s.d., representing $17 \%$ of their income from all sources (Fig. 4). Extrapolating to all the fishers estimated in the fishery (1037 fishers), the total value of sales of trochus flesh in 2018 calculates to US\$571,000 (WS\$1.48 million).

Based on our observations of catches, we conservatively estimated that $15 \%$ of the harvested trochus were above $90 \mathrm{~mm}$ basal shell width $(\sim 250 \mathrm{~g})$, which is the legal size and preferred for exports. In a related study, we calculated a total exportable weight of 263 tonnes of trochus shell harvested in Samoa in 2018 (Purcell et al. 2020). At conservative sale prices to exporters of just WS\$5 kg-1 for trochus shells, this volume would equate to US\$507,000.
Fig. 6. Proportion of fishers responding on which items they spent the extra income earned from trochus (Rochia nilotica; only fishers who sold trochus and reported earning greater income, $\mathrm{n}=55)$.

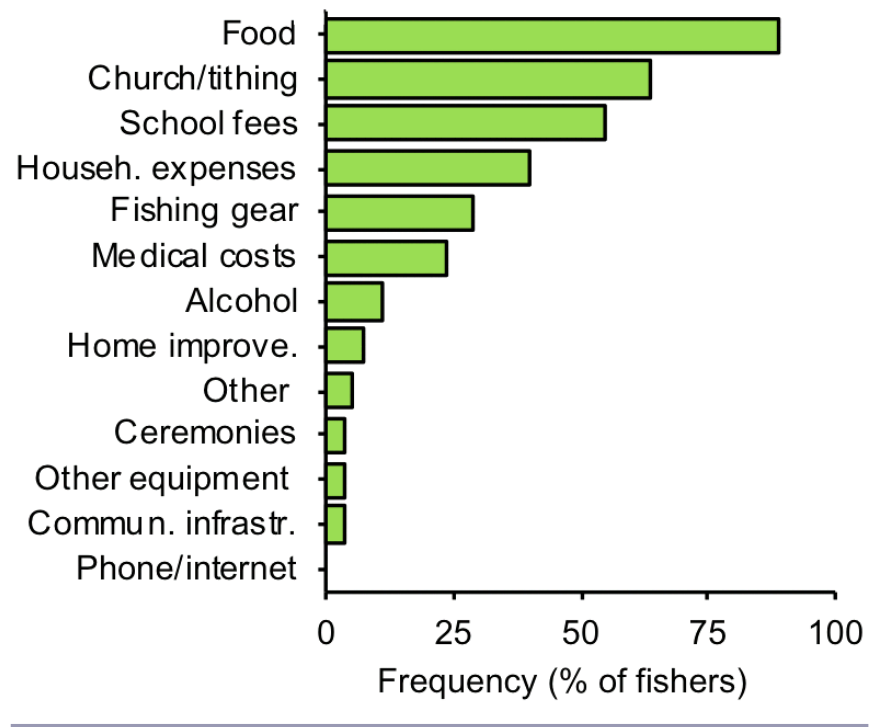

\section{DISCUSSION}

\section{Subsistence consumption}

Trochus introduced to Samoan reefs has diversified seafood consumption and rural incomes. Livelihood diversification benefits from this fishery commenced mostly within the 5-10 years prior to our surveys (Purcell et al. 2020). Our result show that socioeconomic impacts are inclusive because young and old fishers and both men and women harvest trochus. The substantive impacts of trochus to subsistence consumption is an inspiring development in an age when Pacific Island communities still rely heavily on coastal fishing for dietary animal protein and need to diversify seafood supply (Bell et al. 2009). Impacts of this species introduction on hard corals and native edible herbivorous gastropods are unsupported by field data (Seinor et al. 2020, Purcell and Ceccarelli 2021). Notwithstanding, potential ecological impacts to other animals from diminished algal resources and occupancy of refugia remain unstudied.

Trochus are now relatively abundant in Samoa (Purcell and Ceccarelli 2021). Fishers were harvesting an average of 46 trochus shells per day, many of which were small individuals (Purcell et al. 2020). Trochus was harvested in Samoa primarily for local subsistence consumption, and we found that informal markets and noneconomic distribution networks within communities are significant. The tendency for Samoan trochus fishers to share, i.e., give away, part of their catch mirrors similar trends in other subsistence and small-scale fisheries (Barnes-Mauthe et al. 2013, Vaughan and Vitousek 2013, Dacks et al. 2020). Such forms of resource sharing serve to maintain culture, social connections, and reciprocity in sharing of other resources and services within communities (Vaughan and Vitousek 2013, Kittinger et al. 2015). Such sharing of fishery harvests can also bolster resilience at the community level (Vaughan and Vitousek 2013). This is especially 
pertinent for resilience of social-ecological systems disrupted by natural disasters, e.g., cyclones or tsunamis, economic crises, and global pandemics (Bennett et al. 2020).

Previously, the value of the fishery was measured by sales of the flesh at roadside stalls and town markets (Tiitii and Aiafi 2016). Because just $29 \%$ of fishers sold their catch, our study highlights that seafood trade in extensive informal social networks should also be measured in order to fully reveal the importance of fisheries. This study also shows that the culture of resource sharing transcends to newly developed fisheries.

Subsistence fisheries are especially important in the Pacific Islands for food supply (Kuster et al. 2005, Watson et al. 2016, Gillett and Tauati 2018). Data elucidating the landing fate of marine resources, including catch for subsistence consumption, inform our understanding of the contribution of fisheries to local food security (Chuenpagdee et al. 2006, Kronen et al. 2007). For instance, reef fishers in Indonesia, Hawaii, and Kiribati use most of their catch for subsistence consumption rather than an income source (Kittinger et al. 2015, Watson et al. 2016, Furkon et al. 2019). The predominance of consumptive use of trochus in Samoa contrasts with a history of harvesting for its shell in other countries (Nash 1993). Differing extents of trochus consumption among villages in our study are consistent with observations of large geographic variations in shellfish consumption within other Pacific Island countries (Kronen et al. 2007).

\section{Fishing income and costs}

Small-scale fishing households rarely depend on just one livelihood source, and fishers often harvest a variety of seafood (Cinner and Pollnac 2004, Kittinger et al. 2015, Purcell et al. 2016). A diverse catch composition provides a buffer to seasonal variation in resource abundance and market prices, and allows for opportunism during fishing. The newly developed trochus fishery in Samoa has diversified coastal income sources, thereby building adaptive capacity to the risk of livelihood failure through declining fisheries (Allison and Ellis 2001, Bell et al. 2009). This is germane in view that long-lived reef resources are declining and island fisheries will benefit from short-lived, fast-growing invertebrates (Cohen and Foale 2013).

Artisanal fishers often benefit from a range of income streams, such as agriculture, tourism, construction, handicrafts, and transport (Cinner and Pollnac 2004, de la Torre-Castro et al. 2017, Stacey et al. 2019). Coastal fishers are also facing economic hardship from market disruptions and a slump in tourism as a result of the COVID-19 pandemic (Bennett et al. 2020). Trochus contributed $17 \%$ of annual income for approximately 300 Samoan fishers selling the flesh across the whole fishery. Cash has become an increasing necessity for services in Pacific Island communities, even in rural areas (Pollard and Abbott 2004). The diversification of fishery income from this introduced species has fortuitously strengthened the resilience of the social-ecological system to cope with shocks, such as global pandemics. During the year of this study (2018), the total value of income generation was US\$508,000, providing evidence of a substantial return on investment from the original cost of the translocation program (US\$223,000).

Social norms in some fisheries hold that men are responsible for income generation while women take care of household duties (Fröcklin et al. 2014, de la Torre-Castro et al. 2017, Biswas 2018) and wealth might be held by young men (Barclay et al. 2019). However, this stereotype is an overgeneralization for most SSFs (Harper et al. 2013, Biswas 2018). In the Pacific Islands, in particular, women contribute substantially to fishery-based income of households (Harper et al. 2013). Our study furnishes an important example in which small-scale fishing income was gender equitable and inclusive because annual income from selling trochus was primarily due to how often (per week) fishers went fishing and, statistically, had little to do with gender or age.

A main driver of catch rates and fishery income in Samoa was access to a boat. Across fisheries globally, boat owners tend to earn more than nonowners (Teh et al. 2020). In some fisheries, women's limited access to fishing equipment restricts their access to certain fishing grounds and consequently reduces their catches and income (Fröcklin et al. 2014). Boats have been provided as an aid to support, or rebuild, fishery livelihoods (Tewfik et al. 2008). Our findings show that fishing capital can strongly affect fishery catches and economic impacts.

A proposed management plan for the fishery includes minimum legal-size limits, a prohibition on nighttime collection, and the provision for seasonal closures. The minimum size limit of $9 \mathrm{~cm}$ shell width would serve to safeguard yield-per-recruit and eggper-recruit of trochus while also satisfying size requirements for potential exports of the shells (Nash 1993). The management plan specifies the possibility for shell exports, contingent on a ministerial decision, which could potentially nearly double the present income of fishers. Our data also indicate that keeping the shell intact would not take fishers more time. Intact shells can be stockpiled to await sale for export (Gillett and Tauati 2018). We also installed equipment and held capacity building workshops on both Upolu and Savai'i islands to train villagers in skills to polish shells and make shell jewelry for sale. In contrast to exports of whole shells for button manufacturing, the potential industry in trochus shell jewelry and handicrafts would demand few shells.

\section{Other well-being dimensions}

Well-being in fisheries is increasingly influencing fisheries policies, and data on well-being helps to understand fishers' motivations (Coulthard 2012). Psychological measures of happiness offer important dimensions of well-being (Pollnac and Poggie 2006, Coulthard et al. 2015). In many Southeast Asian small-scale fisheries, e.g., Philippines, Indonesia, and Vietnam, fishers like their occupation, are satisfied with their income, and would not leave fishing for an alternative occupation (Pollnac et al. 2001). In Samoa, more than $80 \%$ of trochus fishers were satisfied with the income made from the fishery. In comparison, fishers in some other island fisheries, e.g., sea cucumbers, were often dissatisfied with the fishery incomes because of supply chain issues (Purcell et al. 2016).

Fishing costs can represent a large proportion of total fishery earnings (Teh et al. 2020). A relatively rare characteristic of Samoa's trochus fishery is the low fishing cost, averaging just US\$103 per year per fisher, which helps to explain the high rates of satisfaction. Psychological wellness could also be attributable to the economic importance of the fishery to those fishers selling the flesh.

In some cases, increased income in fisheries might spur consumption of alcohol, or other expenses of limited benefit to community development, e.g., alcohol, gambling, and 
transactional sex (Barclay et al. 2019, Hair et al. 2019). This appears not the case in our study, at least based on accounts by men and women fishers. The new income from the fishery allowed fishers to buy more food, contribute to their church, pay for school fees and household expenses. The fishery thus contributes directly and indirectly to food security and social well-being.

\section{CONCLUSION}

Our study provides an encouraging case of livelihood diversification, through the introduction of an herbivorous marine gastropod to Pacific Island reefs. We find that Samoa's trochus fishery is primarily contributing to food security and is also diversifying income generation of fishers. In addition to these objective well-being measures, satisfaction of hundreds of fishers and the contribution of trochus catches in sharing networks within communities further boosts the livelihood impacts. This social-ecological system is a case in which benefits to users were gender equitable; what determined catches and incomes most was whether fishers used a boat and how often they went fishing. Our data further highlight that the distribution of seafood through informal networks within communities can be significant, and might account for an important component of the catch. The underutilization of the trochus shells, which are roughly an equivalent value to the flesh, opens a promising opportunity to add value to the social-ecological system and further improve fisher incomes and well-being.

Responses to this article can be read online at: https://www.ecologyandsociety.org/issues/responses. php/12183

\section{Acknowledgments:}

This study was funded by the Australian Centre for International Agricultural Research (ACIAR) through project FIS/2016/128. We thank Chris Barlow and Ann Fleming for guidance on the research. We also thank two anonymous reviewers for their constructive comments on the manuscript. All contributors involved in data collection were invited to collaborate on the manuscript, and authorship followed the Vancouver Protocol and the Australian Code for the Responsible Conduct of Research 2018. We acknowledge and thank Audrey Tone, Justin Aiafi, Moso Lesa, Atapana Tony, Catherine Esau, and Feu'u Manuao for assistance with data collection. Support was also provided by Southern Cross University, Australia, and the Ministry of Agriculture and Fisheries, Samoa.

\section{Data Availability:}

The datalcode that support the findings of this study are available on request from the corresponding author, SP. The datalcode are not publicly available because they contain personal details of participants that could compromise their privacy and guarantee of anonymity.

\section{LITERATURE CITED}

Allison, E. H., and F. Ellis. 2001. The livelihoods approach and management of small-scale fisheries. Marine Policy 25:377-388. https://doi.org/10.1016/S0308-597X(01)00023-9

Andréfouët, S., A. Bruckner, L. Chabran, J. Campanozzi-Tarahu, and A. Dempsey. 2014. Spread of the green snail Turbo marmoratus in French Polynesia 45 years after its introduction and implications for fishery management. Ocean \& Coastal Management 96:42-50. https://doi.org/10.1016/j.ocecoaman.2014.05.002

Atkinson, A. 1985. Plots, transformations and regression: an introduction to graphical methods of diagnostic regression analysis. Clarendon, Oxford, UK.

Barclay, K., M. Fabinyi, J. Kinch, and S. Foale. 2019. Governability of high-value fisheries in low-income contexts: a case study of the sea cucumber fishery in Papua New Guinea. Human Ecology 47:381-396. https://doi.org/10.1007/s10745-019-00078-8

Barnes-Mauthe, M., K. L. L. Oleson, and B. Zafindrasilivonona. 2013. The total economic value of small-scale fisheries with a characterization of post-landing trends: an application in Madagascar with global relevance. Fisheries Research 147:175-185. https://doi.org/10.1016/j.fishres.2013.05.011

Belhabib, D., U. R. Sumaila, and D. Pauly. 2015. Feeding the poor: contribution of West African fisheries to employment and food security. Ocean \& Coastal Management 111:72-81. https:// doi.org/10.1016/j.ocecoaman.2015.04.010

Bell, J. D., A. Cisneros-Montemayor, Q. Hanich, J. E. Johnson, P. Lehodey, B. R. Moore, M. S. Pratchett, G. Reygondeau, I. Senina, J. Virdin, and C. C. C. Wabnitz. 2018. Adaptations to maintain the contributions of small-scale fisheries to food security in the Pacific Islands. Marine Policy 88:303-314. https:// doi.org/10.1016/j.marpol.2017.05.019

Bell, J. D., M. Kronen, A. Vunisea, W. J. Nash, G. Keeble, A. Demmke, S. Pontifex, and S. Andréfouët. 2009. Planning the use of fish for food security in the Pacific. Marine Policy 33:64-76. https://doi.org/10.1016/j.marpol.2008.04.002

Bell, J. D., J. L. Munro, W. J. Nash, P. C. Rothlisberg, N. R. Loneragan, R. D. Ward, and N. L. Andrew. 2005. Introduction. Restocking and stock enhancement of marine invertebrate fisheries. Advances in Marine Biology 49:1-374. https://doi. org/10.1016/S0065-2881(05)49001-X

Béné, C., S. Devereux, and K. Roelen 2015. Social protection and sustainable natural resource management: initial findings and good practices from small-scale fisheries. FAO, Rome, Italy.

Bennett, N. J., E. M. Finkbeiner, N. C. Ban, D. Belhabib, S. D. Jupiter, J. N. Kittinger, S. Mangubhai, J. Scholtens, D. Gill, and P. Christie. 2020. The COVID-19 Pandemic, small-scale fisheries and coastal fishing communities. Coastal Management 48:336-347. https://doi.org/10.1080/08920753.2020.1766937

Biswas, N. 2018. Towards gender-equitable small-scale fisheries governance and development: a handbook. FAO, Rome, Italy. https://doi.org/10.18356/e999fb85-en

Blasiak, R., and C. C. C. Wabnitz. 2018. Aligning fisheries aid with international development targets and goals. Marine Policy 88:86-92. https://doi.org/10.1016/j.marpol.2017.11.018 
Butler, D. G., B. R. Cullis, A. R. Gilmour, B. J. Gogel, and R. Thompson. 2018. ASReml-R Reference Manual Version 4. VSN International, Hemel Hempstead, UK.

Chapman, M. D. 1987. Women's fishing in Oceania. Human Ecology 15:267-288. https://doi.org/10.1007/BF00888026

Charlton, K. E., J. Russell, E. Gorman, Q. Hanich, A. Delisle, B. Campbell, and J. Bell. 2016. Fish, food security and health in Pacific Island countries and territories: a systematic review. $B M C$ Public Health 16:285. https://doi.org/10.1186/s12889-016-2953-9

Chuenpagdee, R., L. Liguori, M. L. Palomares, and D. Pauly 2006. Bottom-up, global estimates of small-scale marine fisheries catches. Fisheries Centre Research Report 14(8). The Fisheries Centre, University of British Columbia, Vancouver, Canada.

Cinner, J. 2014. Coral reef livelihoods. Current Opinion in Environmental Sustainability 7:65-71. https://doi.org/10.1016/j. cosust.2013.11.025

Cinner, J., and R. B. Pollnac. 2004. Poverty, perceptions and planning: why socioeconomics matter in the management of Mexican reefs. Ocean \& Coastal Management 47(9-10):479-493. https://doi.org/10.1016/j.ocecoaman.2004.09.002

Cohen, P. J., E. H. Allison, N. L. Andrew, J. Cinner, L. S. Evans, M. Fabinyi, L. R. Garces, S. J. Hall, C. C. Hicks, T. P. Hughes, S. Jentoft, D. J. Mills, R. Masu, E. K. Mbaru, and B. D. Ratner. 2019. Securing a just space for small-scale fisheries in the Blue Economy. Frontiers in Marine Science 6:171. https://doi. org/10.3389/fmars.2019.00171

Cohen, P. J., and S. J. Foale. 2013. Sustaining small-scale fisheries with periodically harvested marine reserves. Marine Policy 37:278-287. https://doi.org/10.1016/j.marpol.2012.05.010

Coulthard, S. 2012. What does the debate around social wellbeing have to offer sustainable fisheries? Current Opinion in Environmental Sustainability 4:358-363. https://doi.org/10.1016/ j.cosust.2012.06.001

Coulthard, S., D. Johnson, and J. A. McGregor. 2011. Poverty, sustainability and human wellbeing: a social wellbeing approach to the global fisheries crisis. Global Environmental Change 21:453-463. https://doi.org/10.1016/j.gloenvcha.2011.01.003

Coulthard, S., N. Paranamana, L. Sandaruwan, R. Manimohan, R. Maya, O. Amarasinghe, D. Koralgama, E. Britton, C. Bene, J. A. McGregor, N. Pouw, C. Abunge, P. Mbatha, R. Ramacandran, P. Ramachandran, and T. Daw. 2015. Exploring wellbeing in fishing communities (South Asia): methods handbook. University of Northumbria, Newcastle, UK.

Dacks, R., T. Ticktin, S. D. Jupiter, and A. M. Friedlander. 2020. Investigating the role of fish and fishing in sharing networks to build resilience in coral reef social-ecological systems. Coastal Management 48:165-187. https://doi.org/10.1080/08920753.2020.1747911

de la Torre-Castro, M. 2019. Inclusive management through gender consideration in small-scale fisheries: the why and the how. Frontiers in Marine Science 6:156. https://doi.org/10.3389/ fmars.2019.00156

de la Torre-Castro, M., S. Fröcklin, S. Börjesson, J. Okupnik, and N. S. Jiddawi. 2017. Gender analysis for better coastal management - increasing our understanding of social-ecological seascapes. Marine Policy 83:62-74. https://doi.org/10.1016/j. marpol.2017.05.015

Faraco, L. F. D., J. Andriguetto-Filho, T. Daw, P. D. C. Lana, and C. F. Teixeira. 2016. Vulnerability among fishers in southern Brazil and its relation to marine protected areas in a scenario of declining fisheries. Desenvolvimento e Meio Ambiente 38:51-76. https://doi.org/10.5380/dma.v38i0.45850

Finkbeiner, E. M. 2015. The role of diversification in dynamic small-scale fisheries: lessons from Baja California Sur, Mexico. Global Environmental Change 32:139-152. https://doi.org/10.1016/ j.gloenvcha.2015.03.009

Foale, S. J., and R. W. Day. 1997. Stock assessment of trochus (Trochus niloticus) (Gastropoda: Trochidae) fisheries at West Nggela, Solomon Islands. Fisheries Research 33:1-16. https://doi. org/10.1016/S0165-7836(97)00062-3

Fong, Q. S., S. Ellis, and M. Haws. 2005. Economic feasibility of small-scale black-lipped pearl oyster (Pinctada margaretifera) pearl farming in the Central Pacific. Aquaculture Economics \& Management 9:347-368. https://doi.org/10.1080/13657300500234359

Fröcklin, S., M. de la Torre-Castro, E. Håkansson, A. Carlsson, M. Magnusson, and N. S. Jiddawi. 2014. Towards improved management of tropical invertebrate fisheries: including time series and gender. PLoS ONE 9(3):e91161. https://doi. org/10.1371/journal.pone.0091161

Furkon, M., N. Nessa, and R. Ambo-Rappe. 2019. Invertebrate gleaning: forgotten fisheries. IOP Conference Series: Earth and Environmental Science 253:012029. https://doi.org/10.1088/1755$\underline{-1315 / 253 / 1 / 012029}$

Gerrard, S., and D. Kleiber. 2019. Women fishers in Norway: few, but significant. Maritime Studies 18:259-274. https://doi. org/10.1007/s40152-019-00151-4

Gillett, R. 2009. Fisheries in the economies of the Pacific Island countries and territories. Asian Development Bank, Manila, Philippines.

Gillett, R., and M. I. Tauati. 2018. Fisheries of the Pacific Islands: regional and national information. FAO, Rome, Italy.

Hair, C., S. Foale, J. Kinch, S. Frijlink, D. Lindsay, and P. C. Southgate. 2019. Socioeconomic impacts of a sea cucumber fishery in Papua New Guinea: Is there an opportunity for mariculture? Ocean \& Coastal Management 179:104826. https:// doi.org/10.1016/j.ocecoaman.2019.104826

Hanich, Q., and M. Tsamenyi. 2009. Managing fisheries and corruption in the Pacific Islands region. Marine Policy 33:386-392. https://doi.org/10.1016/j.marpol.2008.08.006

Harper, S., D. Zeller, M. Hauzer, D. Pauly, and U. R. Sumaila. 2013. Women and fisheries: contribution to food security and local economies. Marine Policy 39:56-63. https://doi.org/10.1016/ j.marpol.2012.10.018

Hauzer, M., P. Dearden, and G. Murray. 2013. The fisherwomen of Ngazidja island, Comoros: fisheries livelihoods, impacts, and implications for management. Fisheries Research 140:28-35. https://doi.org/10.1016/j.fishres.2012.12.001 
Hughes, S., A. Yau, L. Max, N. Petrovic, F. Davenport, M. Marshall, T. R. McClanahan, E. H. Allison, and J. E. Cinner. 2012. A framework to assess national level vulnerability from the perspective of food security: the case of coral reef fisheries. Environmental Science \& Policy 23:95-108. https://doi. org/10.1016/j.envsci.2012.07.012

Kawarazuka, N., and C. Béné. 2010. Linking small-scale fisheries and aquaculture to household nutritional security: an overview. Food Security 2:343-357. https://doi.org/10.1007/s12571-010-0079$\mathrm{y}$

Kittinger, J. N., L. T. Teneva, H. Koike, K. A. Stamoulis, D. S. Kittinger, K. L. L. Oleson, E. Conklin, M. Gomes, B. Wilcox, and A. M. Friedlander. 2015. From reef to table: social and ecological factors affecting coral reef fisheries, artisanal seafood supply chains, and seafood security. PLoS ONE 10:e123856. https://doi.org/10.1371/journal.pone.0123856

Kleiber, D., L. M. Harris, and A. C. J. Vincent. 2015. Gender and small-scale fisheries: a case for counting women and beyond. Fish and Fisheries 16:547-562. https://doi.org/10.1111/faf.12075

Kolding, J., C. Béné, and M. Bavinck. 2014. Small-scale fisheries: importance, vulnerability and deficient knowledge. Pages 317-331 in S. M. Garcia, J. Rice, and A. Charles, editors. Governance of marine fisheries and biodiversity conservation: interaction and coevolution. Wiley-Blackwell, Hoboken, New Jersey, USA. https://doi.org/10.1002/9781118392607.ch22

Koralagama, D., J. Gupta, and N. Pouw. 2017. Inclusive development from a gender perspective in small scale fisheries. Current Opinion in Environmental Sustainability 24:1-6. https:// doi.org/10.1016/j.cosust.2016.09.002

Kronen, M., N. Stacey, P. Holland, F. Magron, and M. Power 2007. Socioeconomic fisheries surveys in Pacific Islands: a manual for the collection of a minimum dataset. Secretariat of the Pacific Community, Noumea, New Caledonia.

Kuster, C., V. C. Vuki, and L. P. Zann. 2005. Long-term trends in subsistence fishing patterns and coral reef fisheries yield from a remote Fijian island. Fisheries Research 76:221-228. https://doi. org/10.1016/j.fishres.2005.06.011

Lal, A., and V. Vuki. 2010. The historical development of seaweed farming, including roles of men and women, and prospects for its future development in Fiji. SPC Women in Fisheries Information Bulletin 21:11-16.

Loring, P. A., D. V. Fazzino II, M. Agapito, R. Chuenpagdee, G. Gannon, and M. Isaacs. 2019. Fish and food security in smallscale fisheries. Pages 55-73 in R. Chuenpagdee and S. Jentoft, editors. Transdisciplinarity for small-scale fisheries governance. Springer, Cham, Switzerland. https://doi.org/10.1007/978-3-319-94938-3 4

McCullagh, P., and J. A. Nelder 1989. Generalized linear models. Second edition. Chapman and Hall, London, UK.

Mills, D. J., L. Westlund, G. De Graaf, Y. Kura, R. Willman, and K. Kelleher. 2011. Under-reported and undervalued: small-scale fisheries in the developing world. Pages 1-15 in R. S. Pomeroy and N. L. Andrew, editors. Small-scale fisheries management: frameworks and approaches for the developing world. CABI International, Oxford, UK. https://doi.org/10.1079/9781845936075.0001
Nash, W. J. 1993. Trochus. Pages 451-496 in A. Wright and L. Hill, editors. Nearshore marine resources of the South Pacific. Institute for Pacific Studies, Suva, Fiji.

Nayak, P. K., L. E. Oliveira, and F. Berkes. 2014. Resource degradation, marginalization, and poverty in small-scale fisheries: threats to social-ecological resilience in India and Brazil. Ecology and Society 19(2):73. https://doi.org/10.5751/ES-06656-190273

Pollard, S., and D. Abbott. 2004. Hardship and poverty in the Pacific: strengthening poverty analysis and strategies in the Pacific. Asian Development Bank, Manila, Philippines.

Pollnac, R. B., and J. J. Poggie. 2006. Job satisfaction in the fishery in two Southeast Alaskan towns. Human Organization 65:329-339. https://doi.org/10.17730/humo.65.3.3j2w39a21tq3j411

Pollnac, R. B., R. S. Pomeroy, and I. H. T. Harkes. 2001. Fishery policy and job satisfaction in three Southeast Asian fisheries. Ocean \& Coastal Management 44:531-544. https://doi. org/10.1016/S0964-5691(01)00064-3

Purcell, S. W., and D. M. Ceccarelli. 2021. Population colonization of introduced trochus (Gastropoda) on coral reefs in Samoa. Restoration Ecology 29(1):e13312. https://doi.org/10.1111/ $\underline{\text { rec. } 13312}$

Purcell, S. W., W. Lalavanua, B. R. Cullis, and N. Cocks. 2018. Small-scale fishing income and fuel consumption: Fiji's artisanal sea cucumber fishery. ICES Journal of Marine Science 75:1758-1767. https://doi.org/10.1093/icesjms/fsy036

Purcell, S. W., P. Ngaluafe, S. J. Foale, N. Cocks, B. R. Cullis, and W. Lalavanua. 2016. Multiple factors affect socioeconomics and wellbeing of artisanal sea cucumber fishers. PLoS ONE 11(12): e0165633. https://doi.org/10.1371/journal.pone.0165633

Purcell, S. W., A. Tagliafico, B. R. Cullis, and B. J. Gogel. 2020. Understanding gender and factors affecting fishing in an artisanal shellfish fishery. Frontiers in Marine Science 7:297. https://doi. org/10.3389/fmars.2020.00297

Salmi, P. 2005. Rural pluriactivity as a coping strategy in smallscale fisheries. Sociologia Ruralis 45:22-36. https://doi. org/10.1111/j.1467-9523.2005.00288.x

Santos, A. N. 2015. Fisheries as a way of life: gendered livelihoods, identities and perspectives of artisanal fisheries in eastern Brazil. Marine Policy 62:279-288. https://doi.org/10.1016/j.marpol.2015.09.007

Secretariat of the Pacific Community (SPC) 2015. A new song for coastal fisheries-pathways to change: the Noumea strategy. Secretariat of the Pacific Community, Noumea, New Caledonia.

Seinor, K. M., S. D. A. Smith, M. Logan, and S. W. Purcell. 2020. Biophysical habitat features explain colonization and size distribution of introduced trochus (Gastropoda). Frontiers in Marine Science 7:223. https://doi.org/10.3389/fmars.2020.00223

Siar, S. V. 2003. Knowledge, gender, and resources in small-scale fishing: the case of Honda Bay, Palawan, Philippines. Environmental Management 31:569-580. https://doi.org/10.1007/ $\underline{\mathrm{s} 00267-002-2872-7}$ 
Stacey, N., E. Gibson, N. R. Loneragan, C. Warren, B. Wiryawan, D. Adhuri, and R. Fitriana. 2019. Enhancing coastal livelihoods in Indonesia: an evaluation of recent initiatives on gender, women and sustainable livelihoods in small-scale fisheries. Maritime Studies 18:359-371. https://doi.org/10.1007/s40152-019-00142-5

Teh, L. C. L., Y. Ota, A. M. Cisneros-Montemayor, L. Harrington, and W. Swartz. 2020. Are fishers poor? Getting to the bottom of marine fisheries income statistics. Fish and Fisheries 21:471-482. https://doi.org/10.1111/faf.12441

Tewfik, A., N. L. Andrew, C. Bene, and L. Garces. 2008. Reconciling poverty alleviation with reduction in fisheries capacity: boat aid in post-tsunami Aceh, Indonesia. Fisheries Management and Ecology 15:147-158. https://doi.org/10.1111/ j.1365-2400.2008.00597.x

Tiitii, U., and J. Aiafi 2016. Assessment of Samoa's trochus (Tectus niloticus) fishery: history, status and recommendations for management. Secretariat of the Pacific Community, Noumea, New Caledonia / Samoa Ministry of Agriculture and Fisheries, Apia, Samoa.

Tioti, B., and M. Bermudes. 2016. Sandfish (Holothuria scabra) to boost inshore fisheries opportunities in Kiribati. SPC Fisheries Newsletter 149:13-15.

Trimble, M., and D. Johnson. 2013. Artisanal fishing as an undesirable way of life? The implications for governance of fishers' wellbeing aspirations in coastal Uruguay and southeastern Brazil. Marine Policy 37:37-44. https://doi. org/10.1016/j.marpol.2012.04.002

Vaughan, M. B., and P. M. Vitousek. 2013. Mahele: sustaining communities through small-scale inshore fishery catch and sharing networks. Pacific Science 67:329-344. https://doi. org/10.2984/67.3.3

Verbyla, A. P., B. R. Cullis, M. G. Kenward, and S. J. Welham. 1999. The analysis of designed experiments and longitudinal data by using smoothing splines. Journal of the Royal Statistical Society: Series C (Applied Statistics) 48:269-311. https://doi. org/10.1111/1467-9876.00154

Watson, M. S., D. C. Claar, and J. K. Baum. 2016. Subsistence in isolation: fishing dependence and perceptions of change on Kiritimati, the world's largest atoll. Ocean \& Coastal Management 123:1-8. https://doi.org/10.1016/j.ocecoaman.2016.01.012

Weeratunge, N., C. Béné, R. Siriwardane, A. Charles, D. Johnson, E. H. Allison, P. K. Nayak, and M.-C. Badjeck. 2014. Small-scale fisheries through the wellbeing lens. Fish and Fisheries 15:255-279. https://doi.org/10.1111/faf.12016

Weeratunge, N., K. A. Snyder, and C. P. Sze. 2010. Gleaner, fisher, trader, processor: understanding gendered employment in fisheries and aquaculture. Fish and Fisheries 11:405-420. https:// doi.org/10.1111/j.1467-2979.2010.00368.x

Zeller, D., S. Booth, and D. Pauly. 2006. Fisheries contributions to the gross domestic product: underestimating small-scale fisheries in the Pacific. Marine Resource Economics 21(4):355-374. https://doi.org/10.1086/mre.21.4.42629521
Zhao, M., M. Tyzack, R. Anderson, and E. Onoakpovike. 2013. Women as visible and invisible workers in fisheries: a case study of Northern England. Marine Policy 37:69-76. https://doi. org/10.1016/j.marpol.2012.04.013 
Appendix 1. Socioeconomic questionnaire.

\section{Trochus Fisher and Seller Questionnaire - Samoa}

Surveyor:

Fisher name:

Date:

Time start:

Gender: female: male:

age:

Village/place of residence:

Waypoint \#

\section{Introduction to respondents:}

$\star$ Who are we? SCU and MAF. Purpose of project.

$\star$ The questionnaire is part of a project to assess the benefits of the (introduced) Aliao [Rochia nilotica] fishery in Samoa. It will take about 30-40 minutes.

$\star$ This study is funded by the Australian Centre for International Agricultural Research.

$\star$ Your responses are completely voluntary. You can choose to not respond to any questions.

$\star$ Your responses will be kept confidential and will be used in a project report and publications, which will show averages of responses from fishers in the village. Your individual information will not be shown. An Information Sheet gives contact details to get feedback about the project and an address in case you have complaints.

$\star$ Unless otherwise stated, our questions ONLY refer to the introduced Aliao, not Aliao Samoa.

\section{Type and location of fishing}

1. Do you only fish commercially for Aliao or do you also fish/collect other marine resources (to sell)?

Only Aliao:

Other resources too:

2. How long ago was the last time you went fishing for Aliao? days.

3. Do you collect the Aliao by walking on the reef at low tide (gleaning)? Yes

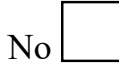

4. Do you collect the Aliao by free-diving/snorkeling? Yes

No

5. In what part of the reef do you go to collect the Aliao??

Reef flat:

Reef crest: $\square$

Front reef slope (3-10 m):

\section{Fishing effort}

6. Over the past 6 months, on how many days did you collect some Aliao each week, on average, during fishing months? days per week.

7. Were there some months that you didn't go out to collect Aliao? If so how many months per year not fishing

If you didn't fish some months, why?

8. If you use a boat to get out to the fishing sites to collect Aliao, what sort of boat?

Canoe paddle only Canoe paddle+sail

Boat with outboard ....engine HP? 
9. If you used an outboard motor, how much fuel did you use on the last trip in which you collected Aliao?

Litres: Cost: How many other people (not including you) shared that cost?

10. What other costs would you have for fishing Aliao?

\begin{tabular}{|l|l|l|}
\hline Item & Cost (Tala) & Per time (day,week,month,year) \\
\hline mask, snorkel & & \\
\hline fins & & \\
\hline wetsuit & & \\
\hline gloves & & \\
\hline sack & & \\
\hline torch & & \\
\hline batteries & & \\
\hline & & \\
\hline
\end{tabular}

11. On a normal day during the past year, how many people are in the group fishing with you?

Are all of them fishing too? Yes $\square$ No $\square \quad \square \quad$ number fishing (not incl. you)

12. On your fishing trips, how many hours are spent to get to and from the fishing sites; i.e. not including the fishing time? Hours round-trip (transportation only).

13. When fishing, how many hours per day would you spend in the water looking for Aliao? hrs.

14. During the past 6 months, how many Aliao (not including Aliao Samoa) would you normally catch on average per day?

On a good day?:

Is this average number that only you personally caught? Yes $\square$ No $\square$ (revise above)

15. Can you rank which marine resources you would, on average, collect the most of, by volume, and which ones you would collect less, by volume? ' 1 ' is most volume, ' 2 ' is second most volume, etc

\begin{tabular}{|c|c|c|}
\hline Fish: & Giant clams: & Turbo shells: \\
\hline Octopus: & Other clams/cockles: & Other gastropods: \\
\hline Lobster: & Aliao Samoa: & Sea urchins: \\
\hline Turtle: & Aliao (giant): & Sea cucumber: \\
\hline Crabs: & Zoanthids: & Other \\
\hline
\end{tabular}

\section{Processing and use}

16. Do you break the Aliao shells to get out the meat or leave shells whole? Break:

Whole:

17. For the Aliao that you catch each month, what proportion would you give away?
All:
Most:
Half:
Small part:
None:

18. For the Aliao that you catch each month, what proportion would you eat yourself?
All: $\square$
Most:
Half:
Small part:
None:

19. For the Aliao that you catch each month, what proportion would you sell?
All:
Most:
Half:
Small part:
None: 
20. Who does the work to get out the meat of the Aliao if you sell the meat?
You:
Spouse:
Children:
Other family member: $\square$ Other (non-family) person:

21. For one average day's catch, how much time do you (and your family) spend to do the work to take out the meat of the Aliao you catch? hrs

\section{Sale of Aliao}

22. Do you catch and sell the Aliao, or do you only sell Aliao that someone else caught?
Catch and sells:
Sells Aliao that someone caught:

We would like to ask you some questions about income you earn from selling Aliao, and you can skip any of the questions if you feel uncomfortable answering them.

23. On a good week, how much money would you earn from the Aliao you sell?

Tala/week

24. This year, how much would you earn on an average week from the Aliao you sell?

Tala/week

25. This year, how much would you earn on average per week from all income sources?

Tala/week

26. How much money did you earn the last time you sold Aliao? \$ Tala

How many shells/pieces was that (total)?

Was that for just one day of fishing? Yes:

No: days

27. Where do you usually sell the Aliao?

Roadside:
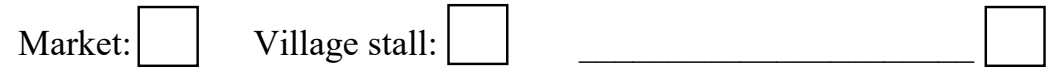

28. Are you satisfied with the money that you earn from selling Aliao?
Very
Mostly
Indifferent:
Not very

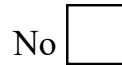

29. Do you ever sell empty Aliao shells, or parts of them (e.g. jewellery)?

Never

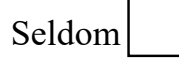

Sometimes

Frequently

30. If you sell the empty shells, what price do you sell each shell for? /shell

31. Has the sale of Aliao increased your weekly income, or has it remained the same, or declined because you are selling Aliao? Increased $\square \quad$ Same $\square \quad$ Declined $\square$

32. If you earn more money now because you are selling Aliao, what things do you most spend that additional income on?

Food $\square$ Alcohol $\square$ School fees $\square$ Other household expenses $\square$ Medical costs $\square$ House improvements $\square$ Improvement of community infrastructure $\square$ Church/tithing $\square$ Boat/fishing gear $\square$ Other equipment $\square$ Funerals, feasts or customary occasions $\square$

Phone/internet credit

Other

Other 


\section{Fishing history and perceptions}

33. How many years ago did you first start collecting the introduced Aliao? years.

34. How many other people do you think are also collecting [introduced] Aliao in your village?

35. Compared to recent years, do you think the numbers of Aliao on the reefs are declining, staying fairly stable, or increasing?

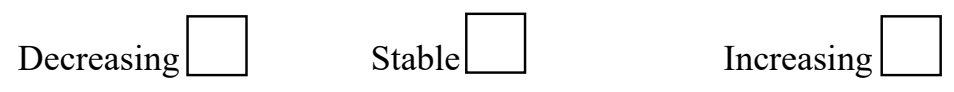

36. Would you be okay if the Ministry of Agriculture and Fisheries brought in a minimum size limit as a fishery regulation for collecting Aliao? No (unhappy) Don't care Okay

37. Would you be okay if MAF brought in a seasonal closure (e.g. for a few months) each year as a fishery regulation for Aliao? No (unhappy) Don't care Okay

Is there any other information or comments that you would like to say? Or do you have any questions?:

Time finished: 


\section{Appendix 2}

TABLE A2.1 I Summary of potential factors and covariates in the analysis of the response variables for the trochus data. Ticks denote the explanatory variables included in the analysis of each response variable.

\begin{tabular}{|c|c|c|c|c|c|c|c|c|c|c|c|c|}
\hline \multirow[b]{2}{*}{ Response } & \multicolumn{4}{|c|}{ Anatomical } & \multicolumn{8}{|c|}{ Secondary variables } \\
\hline & Island & Village & Gender & Age & Surveyor & $\begin{array}{l}\text { Fishing } \\
\text { strategy }\end{array}$ & $\begin{array}{l}\text { Av. days } \\
\text { fishing/week }\end{array}$ & $\begin{array}{l}\text { Hours } \\
\text { fishing/day }\end{array}$ & $\begin{array}{l}\text { Fishing } \\
\text { experience }\end{array}$ & $\begin{array}{l}\text { Where } \\
\text { sold }\end{array}$ & Boat use & $\begin{array}{l}\text { Annual } \\
\text { fishing costs }\end{array}$ \\
\hline $\begin{array}{l}\text { Net annual income from } \\
\text { trochus }\end{array}$ & $\checkmark$ & $\checkmark$ & $\checkmark$ & $\checkmark$ & $\checkmark$ & $\checkmark$ & $\checkmark$ & $\checkmark$ & $\checkmark$ & $\checkmark$ & $\checkmark$ & \\
\hline $\begin{array}{l}\text { Avg. gross income } \cdot \text { day }^{-1} \\
\text { Satisfaction with fishery }\end{array}$ & $\checkmark$ & $V$ & $V$ & $\checkmark$ & $\checkmark$ & $\checkmark$ & $\checkmark$ & $\checkmark$ & $\checkmark$ & $\checkmark$ & $\checkmark$ & $\checkmark$ \\
\hline $\begin{array}{l}\text { income } \\
\text { Perception of change in } \\
\text { income from trochus }\end{array}$ & $\checkmark$ & $\checkmark$ & $\checkmark$ & $\checkmark$ & $\checkmark$ & $\checkmark$ & $\checkmark$ & $\checkmark$ & $\checkmark$ & $\checkmark$ & $\checkmark$ & $\checkmark$ \\
\hline $\begin{array}{l}\text { Proportion of catch } \\
\text { given away } \\
\text { Proportion of catch } \\
\text { eaten }\end{array}$ & $\checkmark$ & $\checkmark$ & $\checkmark$ & $\checkmark$ & $\checkmark$ & $\checkmark$ & & & $\checkmark$ & & & \\
\hline Proportion of catch sold & $\checkmark$ & $\checkmark$ & $\checkmark$ & $\checkmark$ & $\checkmark$ & $\checkmark$ & & & $\checkmark$ & & & \\
\hline
\end{tabular}

